\title{
Impact of Mobile Learning using social media platform on Vocational Student's Achievement Results
}

Alfrina Mewengkang*, Olivia E S Liando, Johan R Batmetan

Manado State University, Sulawesi Utara 95618, Indonesia

\begin{abstract}
This research study was conducted to determine the effect of the mobile learning model using social media platforms on the learning outcomes of $2 \mathrm{~d}$ and $3 \mathrm{~d}$ animation techniques for students of class XI Multimedia at SMK Negeri 1 Tondano. This research uses experimental research in the form of Quasi Experimental Design or quasi-experimental and the research design used in this research is Post-Test Only Control Design. Before the treatment is given in each class, a pre-test is carried out first. After learning, using the Blendend Learning learning model for the experimental class and using conventional methods for the control class. After the learning process is complete, a post-test is carried out for each class. From the results of this post-test, the results obtained are the influence of the Learning Mobile Learning model on the learning outcomes of $2 \mathrm{~d}$ and $3 \mathrm{~d}$ Animation Engineering students of class XI Multimedia SMK Negeri 1 Tondano. The results showed that mobile learning had a positive effect on improving learning outcomes. Finally, the results show that mobile learning changes students' study habits for the better.
\end{abstract}

Keywords: Mobile learning, Social media platforms, Eksperimental research, Vocational

\section{Introduction}

Previously, mobile learning has been developed in the field of informal education. However, in recent years there has been a growing interest for the integration of these technologies in the field of formal education [1]. As a tool for learning regardless of time and place, mobile learning is essential for lifelong learning and access to mobile devices available to everyone today [2]. Nevertheless, a key attribute of any mobile learning is the ubiquity of the mobile device [3].

Educational institutions are currently facing the reality of the rapid development and expansion of cellular phones, which are considered as one of the forms of cellular phones as devices used for E-learning throughout the world [4]. Such developments have involved improvements in both mobile speed and storage capacity [5]. The constant drop in price, on the other hand has resulted in the proliferation of these mobile phones making them one of the main components of the daily life of most students [6]. Cell phones are not accessories anymore; they are integrated like our clothes. It is true that mobile phones are mainly used for communication purposes entirely, but fortunately, some people are starting to consider them to be the core of pedagogical activities in higher education institutions [7]. The number of these teachers and students starting to use them as learning and/or learning tools is growing rapidly. Most of the students have started to overcome their difficulties regarding the place and time of lectures through the effective use of their mobile phones or what is commonly called "Mobile Learning". Teachers, in turn, have started to think seriously about providing their students with teaching materials and activities via their mobile phones. Currently, Mobile Learning has been widely accepted by learners [8]. In other words, learning through mobile devices is widely accepted by the learning community because of its application and philosophy and standards. Mobile Learning (M-Learning) is currently an established methodology [9].

The education unit of SMK Negeri 1 Tondano is one of the schools that has started to implement direct learning in schools since the even semester of the school year 2020/2021. Based on the initial survey in schools, the school began to hold direct learning in schools because of various considerations, one of them was the low learning outcomes of students during online learning during the pandemic, as evidenced by the learning outcomes report which stated that $70 \%$ of students did not reach the KKM set. However, in its implementation, the attendance of students in schools is still limited in accordance with existing health policies and protocols. The attendance of students in class is only about $50-65 \%$ of all students by observing strict health protocols. This then becomes a challenge for the school in dealing simultaneously between offline learning and online learning and how to make offline and online learning run synchronously so that no students are aggrieved in the implementation of this learning. 2D and

\footnotetext{
*Corresponding author : mewengkangalfrina@unima.ac.id
} 
3D Animation Engineering subjects are compulsory vocational subjects for students of class XI Multimedia Department, as well as at SMK Negeri 1 Tondano. In learning 2D and 3D Animation Techniques, students will learn about 2D animation techniques and 3D animation techniques, respectively. In this learning, students not only learn about the theory but are also supported by practical activities so that students can understand the subject matter well. Practical activities are very helpful for students to be able to hone skills and abilities so that they can become qualified and competent graduates. By using the Mobile Learning model, both students who study offline and online can follow the learning materials well together without having to worry about missing out on learning materials. In addition, all learning materials, both theoretical and practical, can be accessed by students anytime and anywhere because learning can use the internet. This can make it easier for students because students can learn 2D and 3D Animation Engineering materials at any time without having to wait to learn in class. Students can also carry out practical activities at home and report to the teacher online. This can be very helpful for students to increase learning motivation and learning outcomes as well.

Based on the background of the research that has been described, the problems that will be discussed in this research are: if there is an Impact of Mobile Learning using social media platform on Vocational Student's Achievement Results in Minahasa Regency.

\section{Research Methods}

The population in this study was the entire class XI Multimedia of SMK Negeri 1 Tondano with a total of 40 students. And the sample taken is the total number of students of class XI Multimedia SMK Negeri 1 Tondano because the population is less than 100 people. Samples were taken randomly or randomly consisting of 20 students for Multimedia 1 class as the experimental class and 20 students for Multimedia 2 class as the control class.

The research method used is an experimental research method in the form of Quasi Experimental Design. The research design used in this study was PostTest Only Control Design [10]. Data that is used as an object must be completely honest, namely the truth that can be trusted [11]. Therefore, we must use the collection method properly and correctly. To get a good instrument, first of all, improvements to the instrument are carried out both in terms of construct validity and language. Research instruments are tools or facilities used by researchers in collecting data so that their work is easier and the results are better so that they are easy to process [12]. The instrument of this research is a written test. The test instrument in this study was a test of learning outcomes of 2D and 3D Animation Techniques in the form of multiple choice (objective), which amounted to 40 questions. The questions were then piloted to a class that had received the subject matter of 2D and 3D Animation Techniques. Questions that have been valid are 32 questions. Because for real research (post-test) must use questions that have been tested for validity, reliability. The analysis technique in this study includes descriptive data, testing the requirements of analytical techniques (testing normality, testing homogeneity and testing hypotheses). After testing the normality of the data and testing the homogeneity of the data, if the data has been declared to be normally distributed and homogeneous, then to determine whether there is an influence of the Mobile Learning model on the learning outcomes of 2D and 3D Animation Engineering students of class XI Multimedia SMK Negeri 1 Tondano, to test the difference in posttest scores from the experimental class and the control class the formula $\mathrm{t}-$ test polled variant with degrees of freedom $(\mathrm{dk})=\mathrm{n} 1+\mathrm{n} 2=2$ with a significant level of $\alpha$ $=0.05$.

\section{Results and Discussion}

\subsection{Descriptive Data}

\subsubsection{Experimental Class Post-Test Result Data}

The data from the post-test results of the experimental class in this study the authors used the help of the Ms. Excel, this research data was taken from the post-test results of class XI Multimedia 1 as an experimental class with 20 students with the mean (average) 89.200, mode 87 , median 86.02 , standard deviation 5.278 and variance 27.85 .

Table 1. Frequency Distribution of Experimental Class Post-Test Results

\begin{tabular}{|c|c|c|c|}
\hline No & Interval & $\begin{array}{c}\text { Absolute } \\
\text { Frequency }\end{array}$ & $\begin{array}{c}\text { Relative } \\
\text { Frequency }\end{array}$ \\
\hline 1 & $81-84$ & 5 & 25 \\
\hline 2 & $85-88$ & 5 & 25 \\
\hline 3 & $89-92$ & 4 & 20 \\
\hline 4 & $93-96$ & 5 & 25 \\
\hline 5 & $97-99$ & 0 & 0 \\
\hline 6 & $100-102$ & 1 & 5 \\
\hline & Total & 20 & 100 \\
\hline
\end{tabular}

Seeing that the mode price is greater than the median price $(\mathrm{Mo}>\mathrm{Me})$, it can be concluded that the post-test data of the experimental class is mostly above the average. When grouped into three parts, those who have a high dick class data score are 25\% (81-84), 20\% (89$92)$, and $0 \%$ (97-99) low. The histogram of the post-test frequency distribution of the experimental class can be seen in Figure 1.

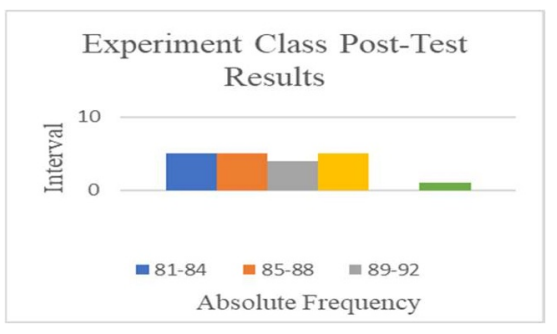

Fig.1. Experimental Class Post-Test Histogram 


\subsubsection{Control Class Post-Test Result Data}

The data from the post-test results of the control class in this study the authors used the help of the Ms. Excel, this research data was taken from the post-test results of class XI Multimedia 2 as the control class with 20 students with the mean (average) 76,700, mode 75, median 78.43, standard deviation 11.367 and variance 122.64 .

Table 2. Frequency Distribution of Control Class PostTest Results

\begin{tabular}{|c|c|c|c|}
\hline No & Interval & $\begin{array}{l}\text { Absolute } \\
\text { Frequency }\end{array}$ & $\begin{array}{l}\text { Relative } \\
\text { Frequency }\end{array}$ \\
\hline 1 & $62-68$ & 5 & 25 \\
\hline 2 & $69-75$ & 4 & 20 \\
\hline 3 & $76-82$ & 4 & 20 \\
\hline 4 & $83-89$ & 3 & 15 \\
\hline 5 & $90-96$ & 3 & 15 \\
\hline 6 & $97-103$ & 1 & 5 \\
\hline & Total & 20 & 100 \\
\hline
\end{tabular}

Seeing that the mode price is smaller than the median $(\mathrm{Mo}<\mathrm{Me})$, it can be concluded that the control class post-test data are mostly below the average. If the data is grouped into three parts, then those who have a high pre-test data score are 5\% (score $97-103$ ), medium $20 \%$ (score $69-75$ ) and low $25 \%$ (score $62-68$ ). The histogram of the post-test frequency distribution for the control class can be seen in Figure 2.

\section{Control Class Post-Test Results}

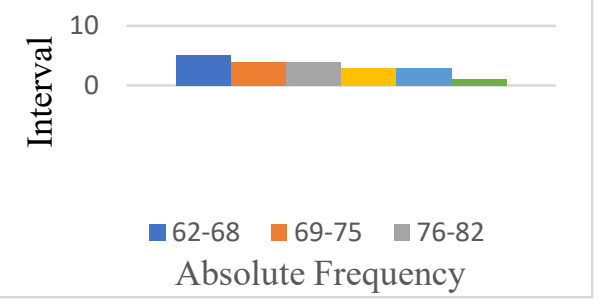

Fig.2. Histogram of the Control Class Post-Test

\subsection{Testing Requirements Analysis}

\subsubsection{Normality Test for Class Experiment}

Table 3. Summary of the Normality Test of Experimental Class Learning Outcomes

\begin{tabular}{|c|c|c|c|}
\hline $\begin{array}{c}\text { Class } \\
\text { Experiment }\end{array}$ & $\left(\mathrm{L}_{\text {count }}\right)$ & $\mathrm{L}_{\text {table }}$ & Conclusion \\
\hline Post-Test & 0,838 & 0.190 & ${\text { Receive } \mathrm{H}_{0}}$ \\
\hline
\end{tabular}

For post-test data on student learning outcomes using the Mobile Learning model (experimental group) can be seen in Table 4.3. It was obtained that $\mathrm{L}_{\text {count }}=0.838$ while $\mathrm{L}_{\text {table }}$ was obtained from a sample of 20 people with a significant level of $\alpha=0.05$ is 0.190 , so the post- test score data for experimental class students' learning outcomes were normally distributed.

$0.838>0.190$, accept Ho because it is normally distributed.

\subsubsection{Normality Test for Class Control}

Table 4. Summary of Normality Test of Control Class Learning Outcomes Data

\begin{tabular}{|l|l|l|l|}
\hline Control Class & $\mathrm{L}_{\text {count }}$ & $\mathrm{L}_{\text {table }}$ & Conclusion \\
\hline Post-Test & 0,162 & 0.190 & Receive $\mathrm{H}_{0}$ \\
\hline
\end{tabular}

For post-test data on student learning outcomes using conventional learning methods (control group) can be seen in the table obtained $\mathrm{L}_{\text {count }}=0.162$ while $\mathrm{L}_{\text {table }}$ is obtained from a sample of 20 people with a significant level of $\alpha=0.05$ is 0.190 then the post-test value data results control class student learning is normally distributed. The complete calculation is seen in Appendix 8.

$0.162<0.190$, accept Ho because it is normally distributed

\section{Homogeneity Test}

The hypothesis to be tested in both groups is

$\mathrm{H}_{\mathrm{o}}: \sigma_{1}^{2}=\sigma_{2}^{2}$ (Both Variances / Same Variety)

$\mathrm{H}_{1}:{\overline{\sigma_{1}^{2}}}_{2} \neq \bar{\sigma}_{2}^{2}$ (Both Variance / Variety are not Equal)

The results of the analysis of the homogeneity test of variance $\mathrm{F}$ on the post-test data, with the experimental class variance: $S_{1}^{2}=27,85$ and class control: $S_{1}^{2}=$ 129,21 give value of $F_{\text {count }}=\frac{\mid 27,85}{129,21}=\mathbf{0 , 2 1}$ while $F_{\text {table }}=$ 2,15. This result shows that $\mathrm{F}_{\text {count }}<\mathrm{F}_{\text {table }}$ or $\mathrm{F}_{\text {count }}=\mathbf{0 , 1 6}$ $<\mathrm{F}_{\text {table }}=\mathbf{2 , 1 5}$ so receive $\mathrm{H}_{\mathrm{o}}: \sigma_{1}^{2}=\sigma_{2}^{2}$. So, the variance of the two classes, namely the experimental class and the control class, is homogeneous or the same.

\subsubsection{Normality Test for Hypothesis Testing}

After conducting the data normality test and data homogeneity test, if the data has been declared to be normally distributed and homogeneous, then to determine whether there is an influence of the Mobile Learning model on the learning outcomes of 2D and 3D animation techniques students of class XI Multimedia SMK Negeri 1 Tondano, to test the difference in pretest/post-test scores of the experimental class and control class used the formula $\mathrm{t}$ - test polled variance with degrees of freedom $(\mathrm{dk})=\mathrm{n} 1+\mathrm{n} 2=2$ with a significant level of $\alpha=0.05$.

The statistical test used for hypothesis testing uses the formula [11]:

$$
\mathrm{t}=\sqrt{\frac{\overline{x 1}-\overline{x 2}}{\sqrt[s]{\frac{1}{n 1}}+\frac{1}{n 2}}}
$$


With sample variance:

$$
\mathrm{s}^{2}=\sqrt{\frac{\left(n_{1}-1\right) s_{1}^{2}+\left(n_{2}-1\right) s_{2}^{2}}{n_{1}+n_{2}-2}}
$$

Explanation:

$\bar{x}_{\mathbf{1}}=$ The average value of the experimental class learning outcomes

$\bar{x}_{2}=$ The average value of the control class learning outcomes

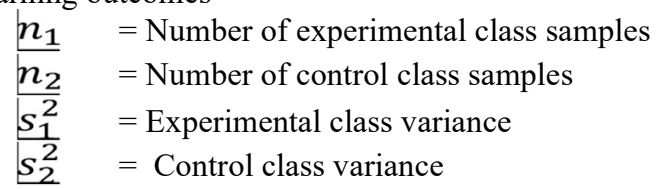

The statistical hypotheses tested are:

$\mathrm{H}_{0}: \mu_{1} \leq \mu_{2}$

$\mathrm{H}_{1}: \mu_{1}>\mu_{2}$

As a criterion for testing the hypothesis Ho is rejected if $t_{\text {count }}>t_{\text {table }}$ (right side test) with $\alpha$ : $0.05 \%$. And data processing is assisted by using Microsoft Excel program.

From the results of hypothesis testing with the -t test, at the level of significance $(\alpha)=0.05$, it is obtained $t_{\text {table }}$ $=2.021$, and $\mathrm{t}_{\text {count }}=7.62$ (attachment 10$)$. So $\mathrm{t}_{\text {count }}=7.62$ $>\mathrm{t}_{\text {table }}=2.021$ which means reject $H_{o}$. Therefore, it can be concluded that the reject $\underline{H_{O}}$ and accept $\mid H_{1}$ are $\underline{\mu_{1}}{ }^{>}$ $\mu_{2}$.

This means that the average student learning outcomes who are taught using the Mobile Learning model in 2D and 3D animation techniques are higher than the average student learning outcomes taught using conventional methods.

Table 5. Statistics of Learning Outcomes in Experiment and Control Classes

\begin{tabular}{|l|l|l|}
\hline \multicolumn{1}{|c|}{ Statistic } & Experiment & Control \\
\hline Sum $\left(\sum\right)$ & 1784 & 1534 \\
\hline Average & 89,200 & 76,700 \\
\hline Minimum Score & 81 & 62 \\
\hline Maximum Score & 100 & 100 \\
\hline Variance (s2) & 27.85 & 122.64 \\
\hline Standard Deviation $(\mathrm{s})$ & 5.278 & 11.074 \\
\hline Lowest Score & 81 & 62 \\
\hline Highest Score & 100 & 100 \\
\hline
\end{tabular}

The data from the research above shows that the average value of the experimental class students' learning outcomes who are taught using the Mobile Learning model is 89,200 with the highest score being 100 and the lowest score being 81 while the control class taught without using the Mobile Learning model is 76,700 with the highest score is 100 and the lowest value is 62 .

These data show the results of the study that the learning outcomes of class XI Multimedia students at SMK Negeri 1 Tondano, especially in 2D and 3D Animation Engineering subjects who take part in learning using the Mobile Learning model are better when compared to the learning outcomes of students who take part in learning without using the Mobile Learning model. This is supported by Tiro (1999: 16) which states that the success of teachers is seen from (1) an increase in the average value, (2) a change in the shape of the distribution from positive to negative skew. The difference in learning outcomes is in accordance with what was stated by Albert Bandura in (Sahabuddin, 2001: 23) which states that behaviour, environment and internal events in students that affect perceptions and actions are interlocking relationships with learning outcomes.

By using the Mobile Learning model in the learning process in the New Normal era, it is expected to make the learning environment faced by students more attractive so that students become more motivated to learn and can improve student learning outcomes.

\section{Conclusions}

Based on the results of the research and discussion conducted, the following conclusions can be drawn: The use of the Mobile Learning model in 2D and 3D Animation Engineering subjects in class XI Multimedia of SMK Negeri 1 Tondano has an effect on learning outcomes. This is evidenced by the data obtained from the learning outcomes of the experimental class that uses the Mobile Learning model to get a higher average score of 89.20 while the control class that does not use the Mobile Learning model gets a lower average score of 76,70 . The difference in student learning outcomes is also proven based on the analysis test carried out using the t-test, which obtained $\mathrm{T}_{\text {count }}=8.62$ and $\mathrm{T}_{\text {table }}=2.02$ so $\mathrm{T}_{\text {count }}=8.62>\mathrm{T}_{\text {table }}=2.02$, with a significance level of 0.05 , which means the Mobile Learning model affects learning outcomes.

The findings of this study also show that Mobile Learning has a positive effect on student learning behaviour. Mobile Learning technology has been determined as a motivational tool for student learning. This shows that students enjoy learning through the use of this technology. In contrast to conventional learning, Mobile Learning makes students more motivated to learn so that they change their learning behaviour. In conclusion, it has been confirmed that mobile technology plays an integral role in enhancing student learning. It specifically helps in improving student learning behaviour and student performance in a positive way.

\section{References}

[1] Sánchez-Prieto, J. C., Olmos-Migueláñez, S., \& García-Peñalvo, F. J. (2016). Informal tools in formal contexts: Development of a model to assess the acceptance of mobile technologies among teachers. Computers in Human Behavior, 55, 519528.

[2] Kob, C. C., Kannapiran, S., \& Shah, A. (2020). The Usage of Mobile Learning: Comparative Studies among Technical and Vocational Education Students in Selected Universities. 
[3] Curum, B., \& Khedo, K. K. (2021). Cognitive load management in mobile learning systems: principles and theories. Journal of Computers in Education, 8(1), 109-136.

[4] C Ali, W. (2020). Online and remote learning in higher education institutes: A necessity in light of COVID-19 pandemic. Higher education studies, 10(3), 16-25.

[5] Oughton, E. J., Frias, Z., van der Gaast, S., \& van der Berg, R. (2019). Assessing the capacity, coverage and cost of $5 \mathrm{G}$ infrastructure strategies: Analysis of the Netherlands. Telematics and Informatics, 37, 50-69.

[6] V Sano, A., Taylor, S., McHill, A. W., Phillips, A. J., Barger, L. K., Klerman, E., \& Picard, R. (2018). Identifying objective physiological markers and modifiable behaviors for self-reported stress and mental health status using wearable sensors and mobile phones: observational study. Journal of medical Internet research, 20(6), e9410.

[7] El-Hussein, M. O. M., \& Cronje, J. C. (2010). Defining mobile learning in the higher education landscape. Journal of Educational Technology \& Society, 13(3), 12-21.

[8] Alowayr, A., \& Al-Azawei, A. (2021). Predicting mobile learning acceptance: An integrated model and empirical study based on higher education students' perceptions. Australasian Journal of Educational Technology, 38-55.

[9] Romero-Rodríguez, J. M., Aznar-Díaz, I., HinojoLucena, F. J., \& Cáceres-Reche, M. P. (2020). Models of good teaching practices for mobile learning in higher education. Palgrave Communications, 6(1), 1-7.

[10] Sugiyono. 2012. "Metode Penelitian Pendidikan: Pendekatan Kuantitatif, Kualitatif, dan R\&D." Bandung: Alfabeta.
[11]Sudjana. (2005). Metode Statistika, Edisi 6. Bandung: Tarsito.

[12]Arikunto, S. (2010). Dasar-Dasar Evaluasi Pendidikan. Jakarta: Bumi Aksara 